\title{
Peach-Morchella intercropping mode affects soil properties and fungal composition
}

\author{
$\underset{\text { Corresp. } 1}{\text { Haiyan Song }}{ }^{1,2}$, Dong Chen ${ }^{1}$, Shuxia Sun ${ }^{1}$, Jing Li ${ }^{1}$, Meiyan Tu ${ }^{1}$, Zihong Xu ${ }^{1}$, Ronggao Gong ${ }^{2}$, Guoliang Jiang \\ ${ }^{1}$ Horticulture Research Institute, Sichuan Academy of Agricultural Sciences \&Key Laboratory of Horticultural Crop Biology and Germplasm Creation in \\ Southwestern China of the Ministry of Agriculture and Rural Affairs, Chengdu, China \\ College of Horticulture, Sichuan Agricultural University, Chengdu, China \\ Corresponding Author: Guoliang Jiang \\ Email address: jgl22@hotmail.com
}

[Objective] This study aims to explore a three-dimensional planting mode in orchards and provide theoretical basis for the efficient peach-Morchella planting and soil management after Morchella cultivation.

[Methods] Next-generation sequencing was performed to investigate the variations in soil physicochemical properties, enzyme activities and fungal composition under peach-Morchella intercropping for one year and two years, by using the soil without peach-Morchella intercropping as the control group.

[Results] Peach-Morchella intercropping decreased the soil bulk density, and significantly increased the maximum field capacity, non-capillary porosity and total porosity, organic matter, available potassium and available zinc, which together improved soil structure and soil fertility. Besides, the intercropping mode obviously enhanced soil enzyme activities and mineral absorption and transformation in peach orchard soils. The intercropping also resulted in a decline of soil fungal diversity, and the 2-year soil samples were of higher abundance of Zygomycota. More importantly, peach-Morchella intercropping elevated the yields of both peach and Morchella, bringing about obviously higher economic benefits.

[Conclusion] Continuous peach-Morchella intercropping improves the soil structure and fertility while decreases soil fungal diversity, which can contribute to greater economic benefits of the peach orchard. Our findings shed new light on the intercropping-fungus-soil relationship, and may facilitate the further development of peach-Morchella intercropping. 


\section{Peach-Morchella intercropping mode affects soil properties and fungal composition}

2 Haiyan Song ${ }^{1,2}$, Dong $\mathrm{Chen}^{1}$, Shuxia $\mathrm{Sun}^{1}$, Jing $\mathrm{Li}^{1}$, Meiyan $\mathrm{Tu}^{1}$, Zihong $\mathrm{Xu}^{1}$, Ronggao Gong ${ }^{2}$, Guoliang Jiang ${ }^{*}$

$3 \quad{ }^{1}$ Horticulture Research Institute, Sichuan Academy of Agricultural Sciences \&Key Laboratory of Horticultural Crop

4 Biology and Germplasm Creation in Southwestern China of the Ministry of Agriculture and Rural Affairs, Chengdu

5 610066, China;

$6 \quad{ }^{2}$ College of Horticulture, Sichuan Agricultural University, Chengdu 611130, China

7 * Correspondence: Guoliang Jiang jg122@hotmail.com

8 Abstract: [Objective] This study aims to explore a three-dimensional planting mode in orchards and provide 9 theoretical basis for the efficient peach-Morchella planting and soil management after Morchella cultivation.

10 [Methods] Next-generation sequencing was performed to investigate the variations in soil physicochemical 11 properties, enzyme activities and fungal composition under peach-Morchella intercropping for one year and two 12 years, by using the soil without peach-Morchella intercropping as the control group. [Results] Peach-Morchella 13 intercropping decreased the soil bulk density, and significantly increased the maximum field capacity, non-capillary 14 porosity and total porosity, organic matter, available potassium and available zinc, which together improved soil structure and soil fertility. Besides, the intercropping mode obviously enhanced soil enzyme activities and mineral absorption and transformation in peach orchard soils. The intercropping also resulted in a decline of soil fungal diversity, and the 2-year soil samples were of higher abundance of Zygomycota. More importantly, peach-Morchella intercropping elevated the yields of both peach and Morchella, bringing about obviously higher economic benefits. [Conclusion] Continuous peach-Morchella intercropping improves the soil structure and fertility while decreases soil fungal diversity, which can contribute to greater economic benefits of the peach orchard. Our findings shed new light on the intercropping-fungus-soil relationship, and may facilitate the further development of peach-Morchella intercropping.

Keywords: Peach orchard; Intercropping; Morchella; Fungal diversity; Soil physicochemical property; Enzyme activity

The Longquanyi District of Chengdu City has a long history of peach planting. However, the management of peach orchards is largely neglected during the slack season, which causes a serious waste of orchard soils (Liu \& Zhu, 2009). With the accelerated urbanization, the farmland in China is sharply decreasing. Thus, it is extremely urgent to improve the efficiency of land use (Liu, 2013), for which proper intercropping may be an effective and feasible way 
31 serious problems such as soil erosion, frequent pest and disease occurrence. (Nong, 2017). For these reasons, orchard intercropping, a sustainable development practice that integrates the advantages of agriculture and forestry, has become a popular mode in ecological agriculture. As reported, orchard intercropping can improve soil fertility, water and soil conservation, ecological environment and fruit yield and quality (Zeng, 2009). In recent years, the peach industry in Longquanyi has been declining due to some problems such as cultivar aging and degradation, resulting in lower income of fruit farmers. Fruit-vegetable or fruit-mushroom intercropping in orchards during the slack season are considered to improve the land use efficiency and farmers' income in this region.

As a valuable edible and medicinal fungus, Morchella is rich in proteins, amino acids, peptides, vitamins and other nutritious components with anti-cancer, anti-fatigue and immunoregulatory activities (Royse \& May, 1990; Dai \& Yang, 2008; Li, 2018). Currently, the techniques of Morchella cultivation have been relatively well developed, and orchard intercropping of Morchella has been realized. It has been reported that the fruit body of Morchella cultivated with orchard intercropping mode has a higher total amino acid content than that cultivated with conventional field planting (Wei et al., 2020). Fruit-mushroom orchard intercropping has recently become a research topic of great concerns. Chen et al. (2012) conducted intercropping of Pleurotus ostreatus and pear tree, which was found to obviously increase the microbial community in $0-20 \mathrm{~cm}$ soil layer, as well as significantly improve the soil fertility and fruit quality. Intercropping patterns would significantly affect soil fungal diversity, changing soil health status, especially for mushroom cultivation (Shen et al., 2009). To promote fruit body occurrence, mushrooms become the dominant fungus in the soil, and compete with other fungal communities, creating a suitable environment. Zhang et al. (2015) and Nong (2017) studied citrus-Stropharia mushroom intercropping system and observed significant increases in soil carbon and nitrogen content, further proving that Stropharia mushroom could promote the formation and mineralization of active organic carbon and various nitrogen sources. In addition, the kiwifruit orchard intercropping pattern was reported to improve the soil permeability and soil aggregate structure, contributing to loose soils and better growth and development of kiwifruit (Lai et al., 2019). Besides, intercropping of edible fungi including Auricularia sp. and Volvariella volvacea in kiwifruit orchards could improve the yield and quality of fruit, bringing about high ecological and economic benefits (Tian \& Peng, 1993; Su \& Liu, 2014). However, there has been no report on peach-Morchella intercropping yet. In this study, peach-Morchella intercropping was carried out in the peach-planting base of Longquanyi, Chengdu since 2015, and the soil physicochemical properties, enzyme activities and fungal composition were analyzed to investigate the threedimensional planting mode in orchards and provide theoretical basis for better peach-Morchella intercropping and soil management after Morchella cultivation.

\section{Materials and methods}

\section{Morchella cultivation}


63

The Morchella cultivar Chuan Yangdujun No. 1 was provided by Soil and Fertilizer Institute, Sichuan Academy of Agricultural Sciences. The mushrooms were cultivated in the peach-planting base of Changsong specialized cooperatives in Longquanyi, Chengdu (N30 $31^{\prime} 44.55^{\prime \prime}$, E104 $\left.17^{\prime} 49.46^{\prime \prime}\right)$ with the soil-covering mode. The base was built in 2012 with a subtropical humid climate and Wanhujing as the main peach cultivar. The peach trees were planted with tree distance of $2.5 \mathrm{~m}$ and row distance of $5 \mathrm{~m}$. Morchella was cultivated in the idle fields between peach trees. The seeds were sown in November with the amount of $300-500 \mathrm{~g} \cdot \mathrm{m}^{-2}$, and covered with $2-3 \mathrm{~cm}$ thick soil for heat and water preservation. Afterwards, a shelter with arched plastic and shading net was constructed to supply a suitable environment for Morchella growth. About 2 weeks later when the hypha grew out of the soil, the transformation bags were placed in the field with a density of five bags per $\mathrm{m}^{-2}$ for nutrition supply. Then, Morchella form fruit bodies at appropriate time. The harvest time was in February to late March of the next year. After the harvest, the transformation bags were cut and dried for a month, and then the remaining materials inside were poured into the peach-Morchella intercropping fields.

\section{Soil sample collection}

A total of three soil treatments were conducted, including one-year peach-Morchella intercropping, two-year peachMorchella intercropping and the control group without peach-Morchella intercropping (the monoculture peach), and the corresponding soil samples were designated as PM-1, PM-2 and PM-CK, respectively. The PM-2 soil samples were collected from the field where Morchella was intercropped in the peach orchard from 2015 to 2016 , while the PM-1 soil samples were collected from the peach orchard with Morchella intercropping just in 2016. Each treatment included three replicates, with each replicate comprising 10 peach trees in a field area of about $150 \mathrm{~m}^{2}$. The distance between each treatment was more than $5 \mathrm{~m}$. After the harvest of Morchella in April, 2017, three sampling sites were randomly selected along a S-shaped curve in each treatment area. Each sampling point was more than $1 \mathrm{~m}$ away from the peach tree trunk, and the distance between any two adjacent sampling points was no less than 5 m. Soil samples at the depth of 0-20 cm were collected after the removal of surface litter layer. The physical properties of the soil were measured with samples collected by ring knife and aluminum box sampling. Additional samples were then taken at each point for chemical property and molecular biological analysis.and soil fungal diversity.

\section{Physicochemical determination of soil samples}

Soil samples from different treatments were collected and the physicochemical properties were determined, including soil bulk density, maximum field capacity, capillary capacity, noncapillary porosity, capillary porosity, total porosity, moisture content, soil specific gravity, $\mathrm{pH}$ value, organic matter, total nitrogen, total phosphorus, 
92 available nitrogen, available phosphorus, available potassium and available zinc. Determination of soil bulk density, maximum field capacity, capillary capacity, noncapillary porosity, capillary porosity, total porosity, moisture content and soil specific gravity was performed by referring to NYT 1121.4-2006 (Measurement method from the popularized agricultural standards). $\mathrm{pH}$ value was tested using a pH510 table acidometer (EUTECH) based on NYT 1377-2007. Organic matter, total nitrogen, total phosphorus, available nitrogen, available phosphorus, available potassium and available zinc were determined according to the methods reported by Ji (2005), Tang et al. (2009), Zhang (2008), Wang (2008) and Gawryluk, Wyupek \& Pawe (2020).

\section{Soil enzyme activity determination}

Potassium permanganate ultraviolet spectrophotometry was used to determine the catalase activity (Yang et al., 2011). About $2.00 \mathrm{~g}$ soil was weighed and put into a $100 \mathrm{~mL}$ triangle flask, which was added with $40 \mathrm{~mL}$ of distilled water and then $5 \mathrm{~mL}$ of $0.3 \% \mathrm{H}_{2} \mathrm{O}_{2}$, followed by shaking for $20 \mathrm{~min}$. The samples were then added with $1 \mathrm{~mL}$ of saturated alum, immediately filtered and put to a triangle flask containing $5 \mathrm{~mL}$ of $3 \mathrm{~N}$ sulfuric acid. After draining, $25 \mathrm{~mL}$ of filtrate was absorbed and titrated to purple with $0.1 \mathrm{~N}$ potassium permanganate solution. At the same time, a soilless control was performed. DNS colorimetry was used to determine the sucrase and cellulase activity ( $\mathrm{Li} \&$ Zheng, 2016). About $2.00 \mathrm{~g}$ of fresh soil was put into a $50 \mathrm{~mL}$ triangle flask and injected with $15 \mathrm{~mL} 8 \%$ sucrose solution, $5 \mathrm{~mL}$ pH 5.5 phosphate buffer and $0.25 \mathrm{~mL}$ toluene. The sample was shaken fully and put into an incubator, cultured at $37^{\circ} \mathrm{C}$ for $24 \mathrm{~h}$, and then taken and filtered quickly. Then, $1 \mathrm{~mL}$ of filtrate was taken and put into a 50 -mL capacity flask, followed by the addition of $3 \mathrm{~mL}$ DNS solution and heating in a water bath with boiling water for 5 min. Then, the volumetric flask was moved to tap water and cooled for $3 \mathrm{~min}$. The solution was orange yellow due to the formation of 3-amino-5-nitrosalicylic acid, and was diluted to $50 \mathrm{~mL}$ with distilled water. Colorimetric measurement was then performed on a spectrophotometer at $508 \mathrm{~nm}$ wavelength. In order to eliminate the errors caused by the original sucrose and glucose in the soil, a control without substrate (without sucrose) should be performed for each soil sample, and a control without soil should be conducted for the whole experiment. For cellulase activity, about $10 \mathrm{~g}$ of soil was put into a $50 \mathrm{~mL}$ triangle flask, which was added with $1.5 \mathrm{~mL}$ toluene,

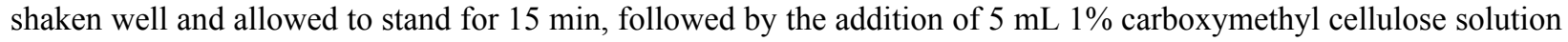
and $5 \mathrm{~mL} \mathrm{pH} 5.5$ acetate buffer, and then culturing in a $37^{\circ} \mathrm{C}$ incubator for $72 \mathrm{~h}$. After culturing, the sample was filtered and $1 \mathrm{~mL}$ of filtrate was taken for colorimetric measurement with the standard curve. In order to eliminate the errors caused by the original sucrose and glucose in the soil, a control without matrix should be performed for each soil sample, and a control without soil should be conducted for the whole experiment. The urease activity was investigated by indophenol blue colorimetry following the descriptions of Huang, Li \& Zhang (2012). About $5 \mathrm{~g}$ of soil was weighed and put into a 50-mL triangle flask, followed by the addition of $1 \mathrm{~mL}$ toluene and shaking, and then addition of $10 \mathrm{~mL} \mathrm{10 \%} \mathrm{urea} \mathrm{solution} \mathrm{and} 20 \mathrm{~mL}$ citrate buffer solution $(\mathrm{pH} 6.7)$ after 15 min. The mixture was 
124

125

126

127

128

129

130

131

132

133

134

135

136

137

138

139

140

141

142

143

144

145

146

147

148

149

150

151

152

153

154

well shaken and incubated in a $37^{\circ} \mathrm{C}$ incubator for $24 \mathrm{~h}$. After culturing, the mixture was filtered, and then $1 \mathrm{~mL}$ of filtrate was taken and added to a $50-\mathrm{mL}$ volumetric flask, followed by the addition of $4 \mathrm{~mL}$ sodium phenol solution and $3 \mathrm{~mL}$ sodium hypochlorite solution and shaking. After $20 \mathrm{~min}$, the color was developed and the volume was fixed. Colorimetric measurement was conducted at $578 \mathrm{~nm}$ wavelength of the spectrophotometer within $1 \mathrm{~h}$. Then, excel and SPSS13.0 were used for statistical analysis, and the least significant difference method $(\mathrm{P}<0.05)$ was used for difference analysis.

\section{DNA extraction, PCR amplification and MiSeq sequencing}

More than $500 \mathrm{mg}$ of soils for each sample was for DNA extraction with three biological replications in each treatment for the sake of methodological reproducibility. The cetyltrimethyl ammonium bromide method (CTAB) was employed to isolate total DNA from the soil samples by referring to Li et al. (2017), and a UV spectrophotometer from Eppendorf, Bio. Photometer was used to measure the DNA purity and concentration. Then, an appropriate amount of available sample was taken into the centrifuge tube and diluted to $1 \mathrm{ng} / \mu \mathrm{L}$ with sterile water. The diluted genomic DNA was used as the template, and specific primers with barcode were used for PCR amplification according to the sequencing region. The fungal gene-specific primers were ITS5-1737F (GGAAGTAAAAGTCGTAACAAGG) and ITS2-2043R (GCTGCGTTCTTCATCGATGC). To ensure the efficiency and accuracy of PCR amplification, buffer and high fidelity enzyme (New England Biolabs) were used. The PCR amplification was performed by Beijing Novogene Biotechnology Co., Ltd (Beijing, China) with the conditions described by Oros-Sichler\& Kornelia (2013). The PCR products were fully and equally mixed based on each concentration, and then detected by electrophoresis with $2 \%$ agarose gel. The target product was recovered with the gel recycling kit provided by Qiagen Co., Ltd. Afterwards, the library was constructed with TruSeq ${ }^{\circledR D N A}$ PCR-Free Sample Preparation Kit, which was subsequently quantified by Qubit and Q-PCR. The quantified library was sequenced on HiSeq2500 PE250 (Novogene, Beijing, China).

\section{Sequence and statistical analysis}

A sequence alignment tool with QIIME pipeline version 1.7.0 was applied to cluster high-quality sequences with $\geq$ 97\% similarity into OTUs (Edgar, 2010, Caporaso et al., 2010). In this process, the most abundant sequence of each OTU was chosen to as the representative sequence and the relative abundance of the OTUs was calculated. The OTUs would be removed if they had a $<0.001 \%$ relative abundance of the total sequences across all samples (Bokulich \& Mills, 2013). The OTU relative abundance data were subjected to multivariate statistical analysis in R environment ( $R$ Core Team, 2016). To visualize the distribution of fungal communities in each treatment, an unconstrained ordination (non-metric multidimensional scaling NMDS) was used based on weighted UniFrac distance using the R vegan package (McArdle \& Anderson, 2001; Oksanen, Kindt \& Legendre, 2008). The R 
155

156

157

158

159

160

161

162

163

164

165

166

167

168

169

170

171

172

173

174

175

176

177

178

179

180

181

182

183

184

185

VennDiagram package was used to present the numbers of shared OTUs with a Venn diagram (Chen \& Boutros, 2011). Besides, a heatmap was drawn to hierarchically cluster and analyze the changes (the amount by which each genus deviated in a specific sample from the genus's average across all samples) of the 35 most abundant genera using $\mathrm{R}$ heatmap package (Kolde $R$, 2012). Two fungal alpha diversity indices including observed OTUs and Shannon were rarefied and calculated based on the smallest library size of the samples.

\section{Results}

\section{Variations of soil physicochemical properties in peach orchard}

Peach-Morchella intercropping greatly influenced the physicochemical properties of peach orchard soils (Table 1). Among the eight tested soil physical properties, half of them exhibited extremely significant differences compared with those in the control group, while the other four were not obviously different. Specifically, one-year and twoyear peach-Morchella intercropping obviously decreased soil bulk density, while significantly increased the maximum field capacity, non-capillary porosity and total porosity compared with the control group. However, capillary capacity was not obviously affected by peach-Morchella intercropping. In addition, all the tested soil chemical properties showed increases in values with the duration of peach-Morchella intercropping except for the $\mathrm{pH}$ value. Peach-Morchella intercropping very significantly enhanced organic matter, available potassium and available zinc, particularly two-year intercropping. In addition, two-year peach-Morchella intercropping resulted in extremely significantly higher total nitrogen, total phosphorus and available phosphorus in soils compared with oneyear intercropping and the control. Generally, peach-Morchella intercropping evidently improved soil fertility and soil structure with loosened texture and enhanced water holding capacity, but the duration of the intercropping showed no significant effect on the soil physical properties.

\section{Soil enzyme activities in peach orchard}

To further explore the variations in soil fertility, we determined the activities of four soil-related enzymes, including catalase, sucrase, cellulase and urease (Table 2). As a result, the activities of all these tested enzymes increased with the duration of peach-Morchella intercropping. Peach-Morchella intercropping resulted in significant increases in the activity of catalase and cellulase in soils, particularly the two-year intercropping, which increased activity of cellulase to 3.6 folds as compared with the control. In addition, the sucrase and urease activities in two-year intercropping soils were significantly higher than those in the control; however, no significant differences were observed between the one-year intercropping soil and the control. Overall, continuous peach-Morchella intercropping could obviously improve soil enzyme activities and facilitate mineral absorption and transformation in peach orchard soils.

\section{Taxonomy-based analysis of fungal community}

PeerJ reviewing PDF | (2021:01:56878:1:0:CHECK 27 May 2021) 
186

187

188

189

190

191

192

The soil samples were sequenced and the sequences were clustered into OTUs. As a result, the soil samples from one-year peach-Morchella intercropping were of the largest number of OTUs with an average of 870. However, the soil samples from two-year intercropping had an average of 583 OTUs, which was obviously smaller than that of other two groups. Besides, a total of 273 common fungal OTUs were found in the soils among the three groups (Fig. 1). Among the OTUs classified at the phylum level, Ascomycota and Zygomycota were detected in all groups. As shown in Fig. 2, the most abundant phylum was Ascomycota, accounting for $70.81 \%$ of the total fungal sequences on average, followed by Zygomycota $(26.13 \%$ on average). The relatively less dominant phyla included Basidiomycota, Chytridiomycota, Glomeromycota and Neocallimastigomycota. It is noteworthy that the two-year intercropping soil samples had lower abundance of Ascomycota and higher abundance of Zygomycota relative to other two groups.

To reveal the fungal diversity of different soil samples at the genus level, the dominant genera were clustered in a heatmap (Fig. S1). As a result, 35 genera were clustered and they belonged to the phyla of Ascomycota, Zygomycota and Basidiomycota, accounting for $80.00 \%, 11.43 \%$ and $8.57 \%$, respectively. These genera included Acremonium, Cercophora, Aspergillus, Cladosporium and Tuber. In addition, the differences in dominant genera in different soil samples were investigated. As a result, each group had its specific fungal genera. In particular, one-year intercropping soils had higher abundance of 12 genera such as Acremonium, Cercophora, Aspergillus, Lophodermium and Staphylotrichum, while two-year intercropping soils had higher abundance of eight genera such as Gilbertella, Morchella, Scytalidium and Mortierella. Nevertheless, Trichoderma and Verticillium showed dominance in none of the three soil samples. Hence, it can be inferred that the duration of peach-Morchella intercropping affects the fungal composition in soils to some extent.

\section{Fungal diversity}

Two fungal alpha diversity indices were investigated between the soil samples including observed species and Shannon value (Fig. 3). The largest number (423) of observed species was found in the control group, which was similar to that in the one-year intercropping soils but apparently larger than that in two-year intercropping soil samples (301). Similarly, the control group had the greatest Shannon value (5.01), followed by the one-year and two-year intercropping soils. Moreover, the fungal beta diversity was evaluated by nonmetric multidimensional scaling ordination (Fig. S2). The three soil samples were obviously separated in different quadrants. The control and one-year intercropping soil samples were closer on the first axis, while the one-year and two-year intercropping soils were closer on the second axis, indicating their similar fungal communities. Through the whole fungal diversity analysis above, it was further confirmed that continuous peach-Morchella intercropping would result in a decline of soil fungal diversity.

\section{Economic benefits}


218 To reveal the effects of continuous peach-Morchella intercropping on the economic benefits of the peach orchards,

219

220

221

222

223

224

225

226

227

228

229

230

231

232

233

234

235

236

237

238

239

240

241

242

243

some relevant economic indices were investigated, including peach yield, fresh Morchella yield, cost and net income (Table 3). Specifically, peach-Morchella intercropping was bound to greatly increase the costs like labor, materials and Morchella culture. However, the harvested Morchella fruit bodies brought about higher economic benefits, and the net income of peach orchards with peach-Morchella intercropping was more than three folds that of the control. Furthermore, a shorter duration of intercropping would more significantly increase the yield of Morchella.

\section{Discussion}

\section{Variations in soil physicochemical property contribute to soil structure and fertility improvement}

The present study reveals that Peach-Morchella intercropping has great effects on the soil physicochemical properties in peach orchards. The soil bulk density was detected to be obviously decreased. Soil bulk density and porosity are generally regarded as important indicators to evaluate soil quality, both of which play certain roles in determining the status of water, gas, heat and biology in the soil, and affect the nutrient supply for crops (Gu et al., 2010). Consistent with the present study, Wang et al. intercropped edible fungi in pear orchards and observed an obvious decline in soil bulk density, which is conducive to the formation of soil aggregates and increase of soil porosity (Wang et al., 2010). In addition, the maximum field capacity, noncapillary porosity and total porosity were significantly elevated by peach-Morchella intercropping, particularly noncapillary porosity, which was 6.43 folds that of the control. Similarly, the substrates of planted Stropharia mushroom increased the total porosity of orchard soils, which effectively elevated the soil permeability in the study of Duan et al. (2019). Therefore, orchard intercropping can promote soil aggregate formation and effective porosity, which will further improve soil water storage capacity (Zuazo et al., 2009).

Soil physical and chemical properties are closely related to each other. For example, soil type and particle size have great influence on the alkali-hydro nitrogen content (Nong, 2017). In addition, the dynamic soil nitrogen cycle is affected by soil texture, soil depth and precipitation (Kebeney et al., 2014). Our study revealed an extremely significantly higher content of total nitrogen in two-year peach-Morchella intercropping soils. It was previously found that fruit-mushroom intercropping could facilitate the formation and accumulation of active organic nitrogen in soils (Yong, 2020; Coser et al., 2012; Suman et al., 2006), which may be attributed to the mushroom substrates. The waste substrates contain rich carbon and nitrogen nutrients, and small-molecular organic and short-chain fatty acids are released in the process of substrate decomposition, which can stimulate soil microorganism activity to enhance soil nitrogen fixation. Besides, the substrate nitrogen mostly exists in an organic form, which can efficiently alleviate the nitrogen loss in the soil (Lu et al., 2011; Dai, 2009; Tosti et al., 2012). Besides, the organic matter, total phosphorus, available phosphorus and available potassium in soils were significantly enhanced by peach-Morchella

Peer] reviewing PDF | (2021:01:56878:1:0:CHECK 27 May 2021) 
251

252

253

254

255

256

257

258

259

260

261

262

263

264

265

266

267

268

269

270

271

272

273

274

275

276

277

278

279

280

281

282

283

intercropping in the present study. Phosphorus is an indispensable nutrient for crop growth and development, and is involved in the synthesis of many important compounds. It can improve the resistance of crops against drought, cold and diseases, and potassium deficiency is likely to cause disorders in metabolism during crop growth (Yang et al., 2012). Generally, the increase in available potassium and available phosphorus in this study provided favorable conditions for the growth of peach. Mu and Duan found obvious increases in soil nutrients including organic matter, available phosphorus and available potassium in mushroom-cultivated soils (Mu, 2019; Duan et al., 2019). Furthermore, Gong (2017) also revealed an increase in soil nutrients under an intercropping mode in a time dependent manner, which is similar to the results in the present study. However, the soil $\mathrm{pH}$ value decreased with the intercropping in this study, which is inconsistent with the previous report (Jonathan et al., 2013). In general, soil chemical properties such as organic matter, available nitrogen and available phosphorus can represent the soil fertility to some extent (Zhu et al., 2018). The peach-Morchella intercropping in this study provided better growth conditions for peach growth due to greatly enhanced soil fertility by changing the soil physicochemical properties.

\section{Enhancement of soil enzyme activities affects soil fertility}

Soil enzymes participate in the regulation of soil nutrient cycling and organic matter degradation and mineralization. Their activities can reflect soil carbon cycling capacity as well as the soil property and fertility level (Li et al., 2012). In the present study, continuous peach-Morchella intercropping enhanced the activities of all the tested soil enzymes, including catalase, sucrase, cellulase and urease. As reported, catalase is widely present in soils with the capability of relieving the toxic effect of hydrogen peroxide (Yang et al., 2015). Sucrase affects the carbon transformation in soils (Guo \& Zhao, 2010), while urease is capable of increasing available nitrogen content in soils by catalyzing and decomposing urea into carbon dioxide, water and ammonia, and the decomposed substances supply available nitrogen nutrients for fruit trees (Dennis, Miller \& Hirsch, 2010; Guo et al., 2013). This study applied substrates from the Morchella transformation bag into the soil, which provided a certain amount of organic matter. Organic matter has a great effect on soil enzyme activities (e.g. urease) (Dai \& Chen, 1995). As a result, soil enzyme activity is elevated due to stable enzyme formation through the combination of organic matter with free enzymes (He, 2012). The intercropping pattern in the study of Lai et al. resulted in enhanced activities of urease, sucrase and phosphatase, which would accelerate soil maturation (Lai et al., 2019). Furthermore, secretion from mushrooms may increase the species and amount of soil microorganisms and enzymes, promoting soil acidity and nitrogen accumulation in orchard soils (Coelho et al., 2012; Basilikoa et al., 2012; Phillips et al., 2012). Hence, there is an interactive relationship between soil enzyme activity and organic matter. As a result, peach-Morchella intercropping enhanced soil enzyme activities to improve the soil nutrition (e.g. available nitrogen), which finally contributed to higher fertility of orchard soils in the present study.

\section{Continuous peach-Morchella intercropping decreases soil fungal diversity}

Continuous peach-Morchella intercropping was found to decrease soil fungal diversity in the present study. It has

Peer) reviewing PDF | (2021:01:56878:1:0:CHECK 27 May 2021) 
284

285

286

287

288

289

290

291

292

293

294

295

296

297

298

299

300

301

302

303

304

305

306

307

308

309

310

311

312

313

314

315

316

317

been demonstrated that different systems of land use are of distinctive fungal taxon (Plassart et al., 2019). Shen et al. (2009) reported that Morchella cultivation could significantly affect the Discomycetes community structure in soils, and the fungal abundance decreased with Morchella cultivation, which is in accordance with our results. It was speculated that Morchella becomes the dominant fungus in the soil, and competitively inhibits other fungal communities. However, some other studies revealed an increase in bacterial and fungal diversity during mushroom intercropping (Yang, 2019; Lai et al., 2019). It is worth noting that the two-year intercropping soil samples in our study had lower abundance of Ascomycota and higher abundance of Zygomycota. The Discomycetes in Ascomycotina and Heterobasidiomycetes in Basidiomycetes were found to be the dominant fungi in Morchellacultivated soils in the study of Shen et al. (2009). Zhang et al. (2018) detected 53 fungi from the Morchellacultivated soil, with Pezizomycetes being the dominant class. Moreover, Ascomycota was identified as the predominant phylum, followed by Mortierellomycota and Basidiomycota in the research of Mu (2019). Besides, the abundance of Ascomycota and Basidiomycota was observed to be significantly changed by Ganoderma lucidum cultivation, as reported by Ren et al. (2020). It can be seen that the variations of fungal communities in mushroomcultivated soils depend on multiple factors such as cultivation environment and species type. Meanwhile, research on the bacterial community in mushroom-cultivated soils revealed that Pseudomonas is an important bacterial genus, which can promote the occurrence of Agaricus bisporus fruit bodies and plays a significant role in Morchella sclerotium formation. (Hayes, Randle \& Last, 2010). Furthermore, Xiong et al. analyzed the bacterial community structure in Morchella-cultivated soils, and demonstrated that rich bacterial community structure is conducive to Morchella occurrence (Xiong et al., 2015). Hence, research on bacterial community should be carried out to explore more potential advantages of the peach-Morchella intercropping mode. Soil microbial diversity has a direct impact on soil enzyme activities, thus affecting soil nutrient metabolism and soil fertility (Kumar et al., 2016; Klimek et al., 2016). The intercropping system can enhance interspecific interactions of the underground biota, contributing to the improvement of soil nitrogen supply capacity and increase in total nitrogen content (Li et al., 2018; Dai et al., 2015).

To further explain how continuous peach-Morchella intercropping affected fungal community and soil propertie, RDA analysis was done including catalase activity (CaA), urease activity (UA), available nitrogen (AN), total potassium (TK), pH value, and differently-treated soil samples with the top 10 fungal genera in abundance (Fig.S3). Results showed that the fungal communities of 1 and 2-year soil samples with peach-Morchella intercropping were significantly affected by available nitrogen, while that of control was affected by total potassium and $\mathrm{pH}$ value. Moreover, the abundances of Morchella, Fusarium, Gibberella and Volutella were positively correlated with soil urease activity and available nitrogen, while Chaetomium and Thermomyces were in a positive relationship with catalase activity and $\mathrm{pH}$ value, respectively. Hence, continuous peach-Morchella intercropping promoted the changes of soil fungal community and properties, contributing to a higher fertility of peach orchard soils.

\section{Fruit-mushroom intercropping is of ecological and economic significance}

Long-term monoculture tends to cause soil degradation, while intercropping can improve soil micro-ecosystem and

Peer) reviewing PDF | (2021:01:56878:1:0:CHECK 27 May 2021) 
318

319

320

321

322

323

324

325

326

327

328

329

330

331

332

333

334

335

336

337

338

339

340

341

342

343

344

345

346

347

348

349

physicochemical properties in the farmland (Kou et al., 2010; Pariz et al., 2016). In the present study, the oxygen and root exudates from peach trees helped Morchella to decompose substrates and promoted its mycelial growth. In addition, the carbon dioxide released during Morchella growth could increase the carbon source storage for peach trees, and the enzymes and waste substrates produced by Morchella supplied nutrients for peach trees. Thus, a small but friendly biosphere would be formed. Besides, it has been demonstrated that peach sawdust could accelerate the mycelial growth of Hericium erinaceus and Auricularia cornea. Therefore, it can be speculated that substances produced by peach trees could facilitate the growth and development of Morchella (Shen et al., 2020). The present study revealed higher economic benefits of the peach-Morchella intercropping mode. Similarly, intercropping of Stropharia mushrooms or Dictyophora in grape orchards contributed to higher yields of mushrooms and better soil physicochemical properties. More importantly, the yield and quality of grapes were also improved. Moreover, the edible fungi (e.g. Pleurotus ostreatus) planted under the trees were demonstrated to be of higher nutrition in fruit bodies (Huang et al., 2019). Obviously, the mode can realize coordinated development of fruit and mushroom (Yang et al., 2020). To sum up, the fruit-mushroom intercropping mode such as peach-Morchella intercropping will be an important direction for future fruit and mushroom production.

\section{Conclusion}

In the present study, peach-Morchella intercropping was conducted in Longquanyi district of Chengdu city. As a result, most of the soil physicochemical properties changed for better, including the soil bulk density, maximum field capacity, non-capillary porosity, total porosity, organic matter, available potassium and available zinc. In addition, continuous peach-Morchella intercropping improved soil enzyme activities but decreased soil fungal diversity. Finally, the soil structure and fertility of the studied peach orchards were significantly improved, which possibly contributed to the yield increase of peach and Morchella. The findings provide a theoretical basis for the efficient peach-Morchella intercropping mode and soil management after Morchella cultivation.

\section{Acknowledgments}

This work was funded by National Peach Industry Technical System (CARS-31-Z-12), Tackling key problems of crop and livestock breeding in Sichuan Province during the 13th five year plan (2016NYZ0034), Innovation Capability Upgrading Project of Sichuan's Financial Department (2016ZYPZ-019), Sichuan Youth Science and technology innovation research team (20CXTD0041), Key Rrsearch and Development Support plan in Chengdu (2020-YF09-00065-SN).

\section{References}

Basilikoa N, Stewartb H, Rouletb NT, Mooreb TR. 2012. Do root exudates enhance peat decomposition? Geomicrobiology Journal 29(4): 374-378 DOI:10.1080/01490451.2011.568272.

Bokulich NA, Mills DA. 2013. Improved selection of internal transcribed spacer-specific primers enables quantitative, ultra-high-throughput 
profiling of fungal communities. Applied \& Environmental Microbiology 79:2519-26 DOI: 10.1128/AEM.03870-12.

Caporaso JG, Kuczynski J, Stombaugh J, Bittinger K, Bushman FD, Costello EK, Fierer N, Peña AG, Goodrich JK, Gordon JI, Huttley GA, Kelley ST, Knights D, Koenig JE, Ley RE, Lozupone CA, McDonald D, Muegge BD, Pirrung M, Reeder J, Sevinsky JR, Turnbaugh PJ, Walters WA, Widmann J, Yatsunenko T, Zaneveld J, Knight R. 2010. QIIME allows analysis of high-throughput community sequencing data. Nature methods 7:335-336 DOI:10.1038/nmeth.f.303.

Chen H, Boutros PC. 2011. VennDiagram: a package for the generation of highly-customizable Venn and Euler diagrams in R. BMC Bioinformatics 12(1): 35 DOI: 10.1186/1471-2105-12-35.

Chen SC, Hou DM, Wu WX, Sun WY, Qiu LY. 2012. Influence of interplanting Pleurotus ostreatus on soil biological activity and fruit quality in pear orchard. Journal of Fruit Science 29(4): 583-588 DOI:10.13925/j.cnki.gsxb.2012.04.018.

Coelho JP, Cristino AF, Matos PG, Rauter AP, Nobre BP, Mendes RL, Barroso JG, Mainar A, Urieta JS, Fareleira JMNA. 2012. Extraction of volatile oil from aromatic plants with supercritical carbon dioxide: Experiments and Modeling. Molecules 17(9): 10550-10573 DOI:10.3390/molecules170910550.

Coser TR, Figueiredo CCD, Ramos MLG, Jannuzzi H, Marchão RL. 2012. Carbon recovery obtained by three methods in organic matter fractions of latosol under maize-grass intercropping in the cerrado. Bioscience Journal 28(1):91-97 http:// www.researchgate.net/publication/289309771.

Dai HH, Hu XF, Cao MY, Luo F, Yan CL, Wang J. 2015. Effects of leguminous intercropping on tomato yield, soil nutrients and enzyme activities. Acta Pedologica Sinica 52 (4): 911-918 DOI:10.11766/trxb201405080223.

Dai W, Chen XD. 1995. Correlation of enzyme activities with some soil properties in Beijing low mountain area. Journal of Hebei Forestry College (1): 13-18.

Dai YC, Yang ZL. 2008. A revised checklist of medicinal fungi in China. Mycosystema 27(6): 801-824 DOI:10.13346/j.mycosystema.2008.06.012.

Dai ZG. 2009. Study on nutrient release characteristics of crop residue and effect of crop residue returning on crop yield and soil fertility. Huazhong Agricultural University DOI:10.7666/d.Y1598123.

Dennis PG, Miller AJ, Hirsch PR. 2010. Are root exudates more important than other sources of rhizodeposits in structuring rhizosphere bacterial communities? Fems Microbiology Ecology 72(3): 313-327 DOI:10.1111/j.1574-6941.2010.00860.x.

Duan LH, Gan YH, Zhou B, Jing HW, Fang B, Yue JL, Zhao M. 2019. Effect of Stropharia rugosoannulata under-forest cultivation on soil. Forest Inventory and Planning 44(1):58-63 DOI:10.3969/ j.issn.1671-3168.2019. 01.011.

Edgar RC. 2010. Search and clustering orders of magnitude faster than BLAST. Bioinformatics 26: $2460-2461$ DOI:10.1093/bioinformatics/btq461. 
379

Gawryluk A, Wyupek T, Pawe Wolański. 2020. Assessment of $\mathrm{Cu}, \mathrm{Pb}$ and $\mathrm{Zn}$ content in selected species of grasses and in the soil of the roadside embankment. Ecology and Evolution 10(18) DOI:10.1002/ece3.6627.

Gong S. 2017. The influnce on soil nutrients and microbe of cultivation of Stropharia rugosoannulata in the forest. Shandong Agricultural University DOI:CNKI:CDMD:2.1018.168265.

Gu HY, Jin JB,Chen XW,Wang EH, Zhou YY, Chai YF. 2010. The long-term impacts on chemical properties of Larixgmelini forest on the northern slope of Greater Hinggan Mountains from a forest fire of varying fire intensity. Journal of natural resources (7):1114-1121 DOI: 10.11849/zrzyxb.2010.07.007.

Guo XM, ZhaoTQ. 2010. Spatial characters of soil microbial quantities and enzyme activity in coalmining subsided area. Chinese Journal of Environmental Engineering 4(12):2837-2842.

Guo YJ, Di HJ, Cameron KC, Li B, Podolyan A, Moir JL, Monaghan RM, Smith LC, O'Callaghan M, Bowatte S. 2013. Effect of 7-year application of a nitrification inhibitor, Dicyandiamide (DCD), on soil microbial biomass, protease and deaminase activities, and the abundance of bacteria and Archaea in Pasture soils. Journal of Soils and Sediments 13(4): 753-759 DOI:10.1007/s11368-012-0646-2.

Hayes WA, Randle PE, Last FT. 2010. The nature of the microbial stimulus affecting sporophore formation in Agaricus bisporus (Lange) Sing. Annals of applied biology 64(1):177-187 DOI:10.1111/j.1744-7348.1969.tb02867.x.

He C. 2012. Effect of tabacco continuous cropping on soil carbon content, enzyme activities, utilization ability of carbon resources and microorganism diversity. Henan Agricultural University DOI:10.7666/d.y2157108.

Huang JX, Yuan SN, Pan J, Zheng DH, Chen JM, Li J, Gui Q, Zhou LJ. 2019. Yield of Stropharia rugosoannulata planted under rubber plantation and analysis of its quality of sporophore. Chinese Journal of Tropical Crops 40(1): 018-023 DOI:10.3969/j.issn.10002561.2019.01.003.

Huang J, Li Z, Zhang J. 2012. Improvement of indophenol blue colorimetric method on activity of urease in soil. Journal of Civil, Architectural \& Environmental Engineering 34(1):102-107 DOI:10.3969/j.issn.1674-4764.2012.01.019.

Ji TW. 2005. Comparison on determining the organic matter contents in the soils by different heating methods in the potassium dichromatevolumetric method. Acta Agriculturae Zhejiangensis 17(5):311-313 DOI:10.3969/j.issn.1004-1524.2005.05.017.

Jiang L, Zheng Y, Liu GJ, Wang B, Tian CY. 2017. Characteristics of root distributions of Prunus armeniaca and Medicago sativa and soil physical and chemical properties under orchard intercropping mode. Acta Botanica Boreali-Occidentalia Sinica 37(12) DOI: 10.7606/j.issn.1000-4025.2017.12.2489.

Jonathan SG, Oyetunji OJ, Olawuyi OJ, Uwukhor PO. 2013. Application of Pleurotus ostreatus SMC as soil conditioner for the growth of soybean (Glycine max). Academia Arena 5 (1): 54-61 http://www.sciencepub.net/academia.

Kebeney SJ, Semoka JMR, Msanya BM, Ng'Etich WK. 2014. Effects of nitrogen fertilizer rates and soybean residue management on nitrate 
nitrogen in sorghum-soybean intercropping system. International Journal of Plant \& Soil Science 4 (3): 212-229 DOI:10.9734/IJPSS/2015/12744.

Klimek B, Chodak M, Ja'zwa M, Niklińska M. 2016. Functional diversity of soil microbial communities in boreal and temperate Scots pine forests. European Journal of Forest Research 135 (4): 731-742 DOI:10.1007/s10342-016-0968-5.

Kolde R. 2012. Pheatmap: pretty heatmaps. R package version, 61.

Kumar U, Shahid M, Tripathi R, Mohanty S, Kumar A, Bhattacharyya P, Lal B, Gautam P, Raja R, Panda BB. 2016. Variation of functional diversity of soil microbial community in sub-humid tropical rice-rice cropping system under long-termorganic and inorganic fertilization. Ecological Indicators 73(73): 536-543 DOI:10.1016/j.ecolind.2016.10.014.

Kou JC, Yang WQ, Han MY, Chen A, Li B, Zhang W. 2010. Research progress on interplanting grass in orchard in China. Pratacultural Science 27(7): 154-159 DOI:CNKI:SUN:CYKX.0.2010-07-030.

Lai RL, Long Y, Cheng CZ, Feng X, Wu RJ, Chen YT, Weng BQ. 2019. Model optimized construction and technology integrated application of intercropping in kiwifruit orchard. Chinese Journal of Eco-Agriculture 27(9): 1430-1439 DOI: 10.13930/j.cnki.cjea.190057.

Li CH, Jia ZJ, Tang LS,Wu YC, Li Y. 2012. Effect of model of fertilization on microbial abundance and enzyme activity in oasis farmland soil. Acta Pedologica Sinica 49(3):567-573 DOI:CNKI:SUN:TRXB.0.2012-03-019.

Li HY, Fu TT, Zhang Y, Lv TY, Li Y, Xu BL. 2017. Effect comparison of five methods to extract fungal genomic DNA as PCR templates. Chinese Agricultural Science Bulletin 33(16):28-35 DOI: CNKI:SUN:ZNTB.0.2017-16-007.

Li QS, Chen J, Wu LK, Luo X, Li N, Yasir A, Sheng L, Lin W. 2018. Belowground interactions impact the soil bacterial community, soil fertility, and crop yield in maize/peanut intercropping systems. International Journal of Molecular Sciences 19(2): 622 DOI:10.3390/ijms19020622.

Li WD. 2018. Review of research progress of biological active components and pharmacological effects of Morchella. Edible and medicinal mushrooms 26(3):157-160.

Li ZY, Zheng L. 2016. Soil sucrase: detection conditions based on DNS colorimetric. Chinese Agricultural Science Bulletin 32(27):171-176 DOI: 10.11924/j.issn.1000-6850.casb16010021.

Liu XL. 2013. Agricultural technology popularization behavior choice of peasant household in research. Anhui University DOI:10.7666/d.Y2321696.

Liu XY, Zhu JP. 2009. The Research on content of selenium in fruits in Longquan, Chengdu. Journal of Southwest China Normal University (Natural Science Edition) 34(1):42-45 DOI:CNKI:SUN:XNZK.0.2009-01-009.

Lu WT, Jia ZK, Zhang P, Wang W, Li YP. 2011. Effects of straw returning on soil labile organic carbon and enzyme activity in Semi-arid Areas of Southern Ningxia, China. Journal of Agro-Environment Science 30(3):522-528. 
437

438

439

440

441

442

443

444

445

446

447

448

449

450

451

452

453

454

455

456

457

458

459

460

461

462

463

464

McArdle B H, Anderson M J. 2001. Fitting multivariate models to community data: a comment on distance-based redundancy analysis. Ecology 82(1): 290-297 DOI: 10.1890/0012-9658(2001)082[0290:FMMTCD]2.0.CO;2.

Mu XH. 2019. Physicochemical characteristics and microbial community of Morchella esculenta cultivated soil in Sichuan Province. Sichuan Agricultural University.

Nong JH. 2017. Study on the variation characteristics and relationships of carbon and nitrogen compositions in purple soil under the intercropping system. Southwest University DOI: CNKI:CDMD:2.1017.846774.

Oksanen J, Kindt R, Legendre P. 2008. The VEGAN Package: community ecology package.

Oros-Sichler M, Kornelia S. 2013. Semi-nested PCR approach to amplify large 18S rRNA gene fragments for PCR-DGGE analysis of soil fungal communities. Laboratory Protocols in Fungal Biology. Springer New York 289-298 DOI: 10.1007/978-1-4614-2356-0_23.

Pariz CM, Costa C, Crusciol CAC, Meirelles PRL, Castilhos AM, Andreotti M, Costa NR, Martello JM, Souza DM, Sarto JRW. 2016. Production and soil responses to intercropping of forage grasses with corn and soybean silage. Agronomy Journal 108(6): 2541-2553 DOI:10.2134/agronj2016.02.0082.

Phillips LA, Greer CW, Farrell RE, Germida JJ. 2012. Plant root exudates impact the hydrocarbon degradation potential of a weatheredhydrocarbon contaminated soil. Applied Soil Ecology 52(52): 56-64 DOI:10.1016/j.apsoil.2011.10.009.

Plassart P, Prévost-Bouré NC, Uroz S, Dequiedt S, Stone D, Creamer R, Griffiths RI, Bailey MJ, Ranjard L, Lemanceau P. 2019. Soil parameters, land use, and geographical distance drive soil bacterial communities along a European transect. Scientific Reports 9: e605 DOI:10.1038/s41598-018-36867-2.

R Core Team. 2016. R: a language and environment for statistical computing, Vienna, Austria. URL:https://www.r-project.org/.

Ren F, Zhang Y, Yu H, Zhang YA. 2020. Ganoderma lucidum cultivation affect microbial community structure of soil, wood segments and tree roots. Scientific Reports 10(1) DOI:10.1038/s41598-020-60362-2.

Royse DJ, May B. 1990. Interspecific allozyme variation among Morchella spp. and its inferences for systematics within the genus. Biochemical Systematics and Ecology 18(7/8):475-479 DOI:10.1016/0305-1978(90)90116-W.

Shen H, Wang H, Zhao YC, Feng AP, Chen MJ, Pan YJ. 2009. Analysis of fungal communities present in Morchella growth soil using denaturing gradient gel electrophoresis. Acta Edulis Fungi 16(2):10-16 DOI:10.16488/j.cnki.1005-9873.2009.02.004.

Shen M, Yao XT, Quan XH, Wang RS, Jiang J. 2020. Effects of fruit tree sawdust extract on mycelial growth of edible fungi. Edible Fungi 42(3):14-18 DOI:CNKI:SUN:SIYJ.0.2020-03-007.

Su SH, Liu JP. 2014. Study on interplanting Volvariella volvacea in kiwifruit orchard. Journal of Green Science and Technology (5): $84-86$ DOI: 10.3969/j.issn.1674-9944.2014.05.037. 
465

466

467

468

469

470

471

472

473

474

475

476

477

478

479

480

481

482

483

484

485

486

487

488

489

490

491

Suman A, Lal M, Singh AK, Gaur A. 2006. Microbial biomass turnover in Indian subtropical soils under different sugarcane intercropping systems. Agronomy Journal 98(3):698-704 DOI:10.2134/agronj2005.0173.

Tang QW, Hao QJ, Jiang CS, Wang DY. 2009. Comparison of flow injection analysis method and traditional methods for the determination of nitrogen in soils. Chinese Agricultural Science Bulletin (18):236-240 DOI:CNKI:SUN:ZNTB.0.2009-18-054.

Tian HX, Peng SY. 1993. Study on interplanting of kiwifruit with Auricularia cornea. Journal of Jishou University (Natural Science) 14(6): 50 DOI:CNKI:SUN:JSDN.0.1993-02-011.

Tosti G, Benincasa P, Farneselli M, Pace R, Tei F, Guiducci M, Thorup-Kristensen K. 2012. Green manuring effect of pure and mixed barley-hairy vetch winter cover crops on maize and processing tomato N nutrition. European Journal of Agronomy 43:136-146 DOI:10.1016/j.eja.2012.06.004.

Wang CR. 2008. Determination of soil available potassium and slow-available potassium by different instruments. Hunan Agricultural Sciences (4):86-88 DOI:10.16498/j.cnki.hnnykx.2008.04.007.

Wang YK, Jin GQ, Wang LM, Dong ZP, Ren HS. 2014. Study on eco-economic benefits of pear-grass-chicken-mushrooms complex system in hilly area of Northern Zhejiang Province. Chinese Horticulture Abstracts (9): 10-12 DOI: CNKI:SUN:YUWZ.0.2014-09-006.

Wei ZL, Wei XJ, Li YJ, Zhang XL, Tang SM, He J, Li SH. 2020. Nutrition analysis and comparison of two Morchella strains cultivated in three modes. Edible Fungi 42(4):72-74 http://d.wanfangdata.com.cn/periodical/syj202004025.

Xiong C, Li XL, Li Q, Zheng LY. 2015. Bacteria community structure and diversity in Morchella colonies. Journal of Hunan Agricultural University (Natural Sciences) 41(4):428-434 DOI:10.13331/j.cnki.jhau.2015.04.017.

Yang L, Liu HL, Zhang Q, Wei CX, Yi WJ. 2015. Effect of different organic fertilizers on soil enzyme activity in tea garden. Guizhou Science 33(5): 36-39 DOI:CNKI:SUN:GZKX.0.2015-05-009.

Yang LF, Zeng Q, Li HB, Yan JJ. 2011. Measurement of catalase activity in soil by ultraviolet spectrophotometry. Chinese Journal of Soil Science 42(1):207-210 DOI:10.19336/j.cnki.trtb.2011.01.043.

Yang N, Zhao HB, Wang ZH, Zhang DB, Gao YJ. 2012. Accumulation and translocation of dry matter and nutrients of wheat rotated with legumes and its relation to grain yield in a dryland area. Acta Ecologica Sinica 32(15): 4827-4835 DOI:10.5846/ stxb201107221085.

Yang SQ, Cheng LJ, Zhao QJ, Chen Y, Ran QY, Xiao ZX, Qiu YH, Gao GX. 2020. Effect of cultivation of different edible fungi under grapevines. Acta Botanica Boreali-Occidentalia Sinica 29(7): 1045-1050 DOI:10.7606/j.issn. 1004-1389.2020.07.009.

Yang XQ. 2019. Leaf carbon assimilation of maize and soil microbial biodiversity in maize/oyster mushroom intercropping. University of Chinese Academy of Sciences. 
492

493

494

495

496

497

498

499

500

501

502

503

504

505

506

507

508

509

Yong J. 2020. Effects of straw returned amount on soil nutrients and $\mathrm{CO}_{2}$ emissions under Citrus/mushrooms intercropping system. Southwest University.

Zeng WB. 2009. Study on landscape Pattern of agroforestry ecosystem in the region of Changzhutan. Central South University of Forestry \& Technology DOI:10.7666/d.Y1848322.

10.7671/j.issn.1001-411X.2017.05.008.

Zhang T, Huang XY, Xu YY, Li J. 2018. Study on microbial community structure and diversity of Morchella rhizosphere soil. Jounal of Hebei Agricultural University 41(06):42-47+61 DOI:10.13320/j.cnki.jauh.018.0123.

Zhang XS. 2008. Analysis of the factors affecting the available $\mathrm{P}$ content in the fermentation liquid of $\mathrm{P}$ bacteria determined by Mo-Sb colorimetry. Journal ofAnhui Agri. Sci. (12):4822-4823 DOI:10.3969/j.issn.0517-6611.2008.12.009.

Zhang Y, Liu YJ, Ni JP, Xie DT. 2015. Effect of Citrus tree/ Stropharia mushrooms intercropping on purple soil labile organic carbon in the Three Gorges Reservoir region. Acta Prataculturae Sinica 24(5):53-65 DOI: 10.11686/cyxb20150507.

Zhang Y, Zhang JE, Xiang HM, Gong YL, Luo H, Li DF. 2017. Effects of intercropping on nitrogen component in latosolic red soil of slope land in young orchard. Journal of South China Agricultural University 38(5):43-49 DOI:

Zhu XC, Sun LY, Song FB, Liu S, Li X. 2018. Soil microbial community and activity are affected by integrated agricultural practices in China. European Journal of Soil Science $\mathbf{6 9}$ (5):924-935 DOI:10.1111/ejss.12679.

Zuazo VHD, Pleguezuelo CRR, Panadero LA, Martinez Raya J, Martinez RF, Rodriguez BC. 2009. Soil conservation measures in Rainfed Olive Orchards in South-Eastern Spain: Impacts of plant strips on soil water dynamics. Pedosphere 19(4): 453-464 DOI: 10.1016/S10020160(09)60138-7. 
Figure 1

Venn diagram showing the number of shared OTUs between different soil samples of peach-Morchella intercropping

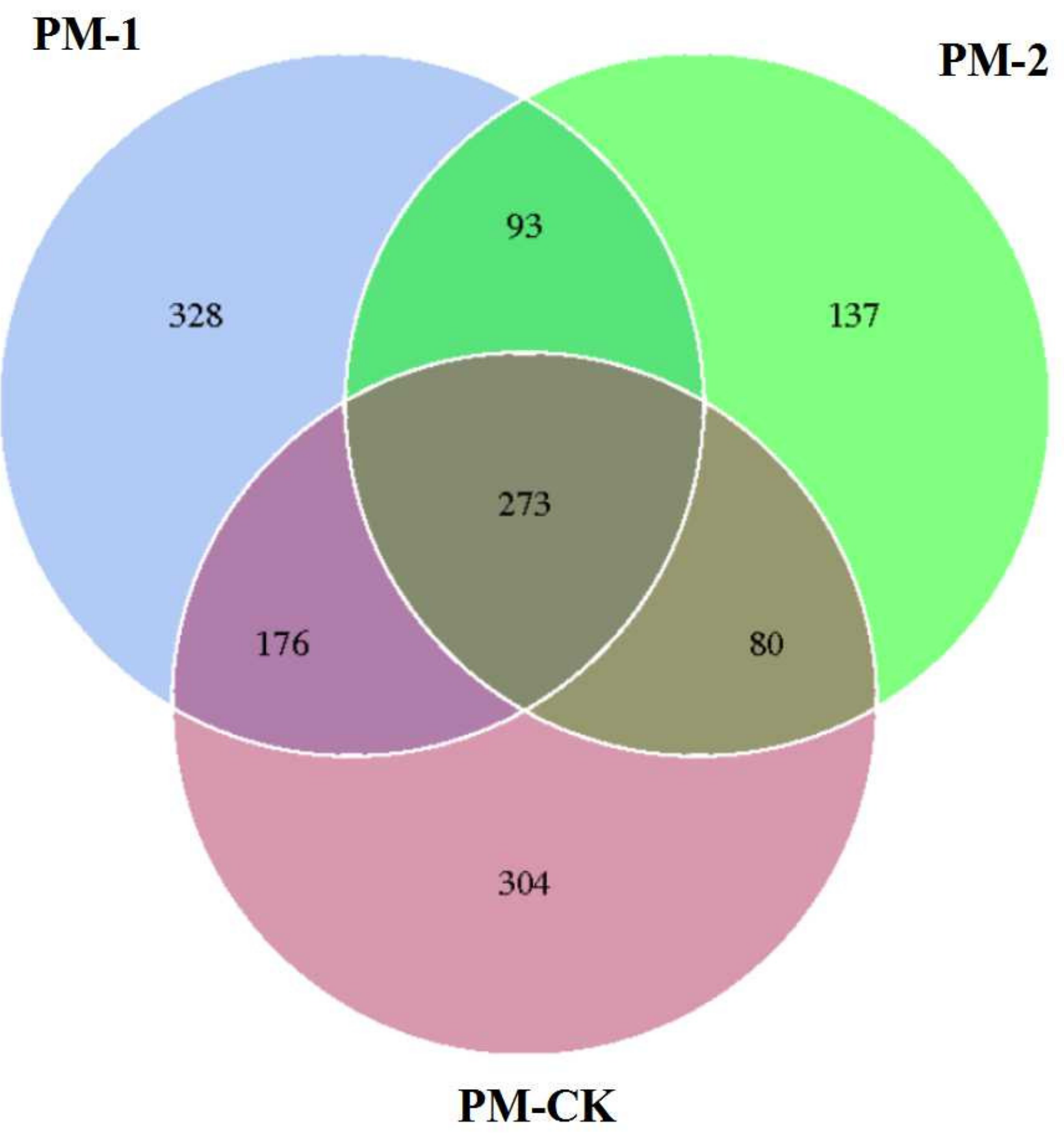




\section{Figure 2}

OTU average relative abundances of the major fungal phyla in the soil samples of peach-Morchella intercropping

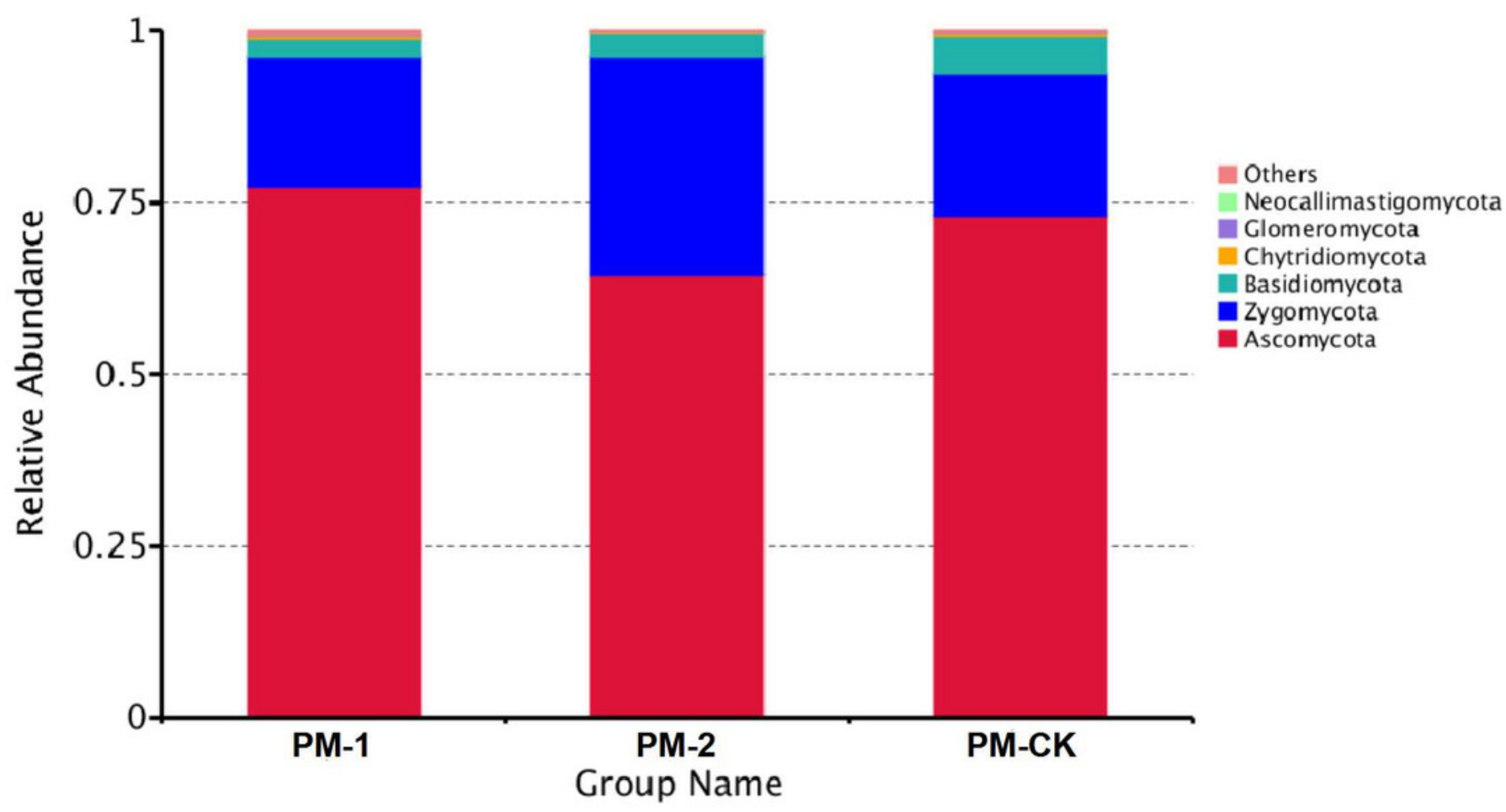


Figure 3

Boxplot showing fungal alpha diversity indices
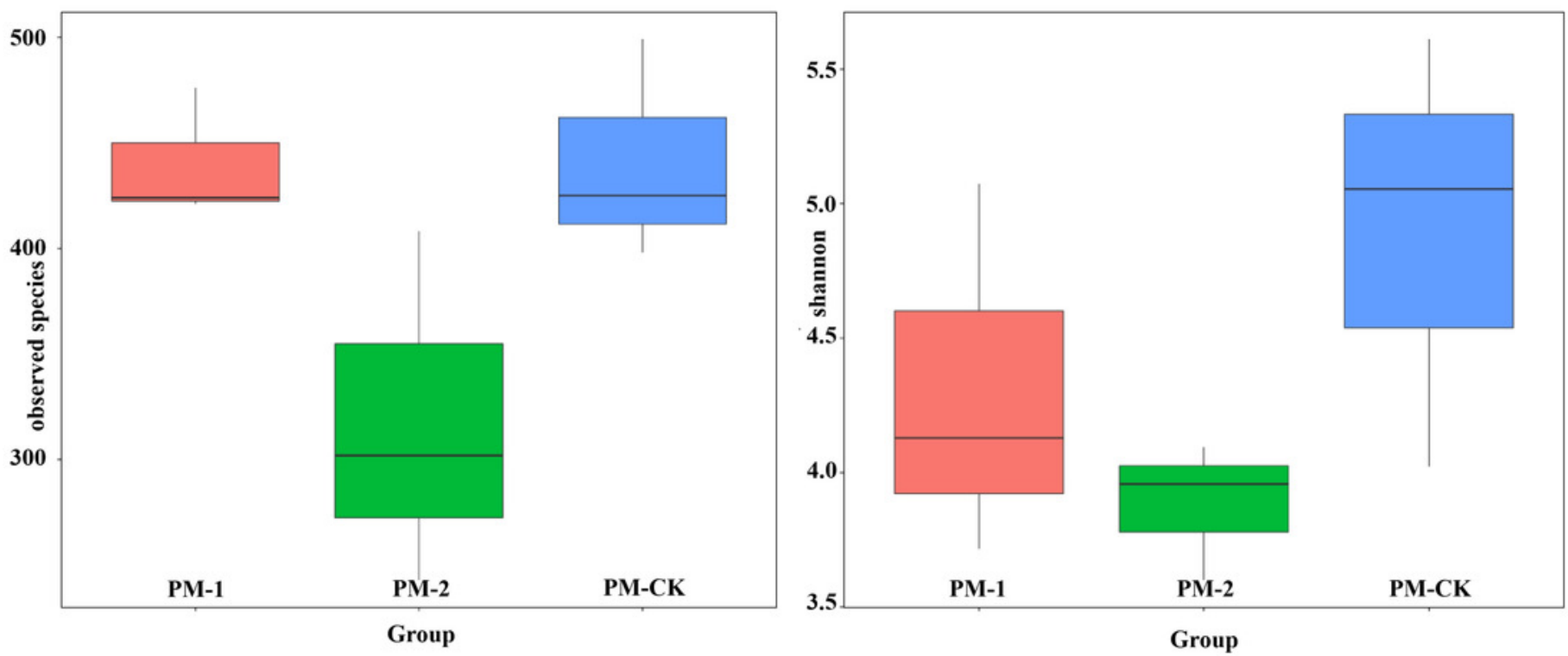


\section{Table $\mathbf{1}$ (on next page)}

Table 1 Soil Physicochemical property changes of soil in peach orchard

Different capital letters showed significant difference at $\mathrm{P}<0.01$, and different lower-case letters showed significant difference at $\mathrm{P}<0.05$ between different treatments. $P M-1$ the soil of peach-Morchella intercropping for 1 year; PM-2 the soil of peach-Morchella intercropping for 2 years; $P M-C K$ the control group without peach-Morchella intercropping. 


\begin{tabular}{|c|c|c|c|c|c|c|c|c|}
\hline NO. & $\begin{array}{l}\text { Soil bulk density } \\
\qquad\left(\mathrm{g} / \mathrm{cm}^{2}\right)\end{array}$ & $\begin{array}{c}\text { Maximum field } \\
\text { capacity (\%) }\end{array}$ & $\begin{array}{c}\text { Capillary } \\
\text { capacity (\%) }\end{array}$ & $\begin{array}{l}\text { Noncapillary } \\
\text { porosity (\%) }\end{array}$ & $\begin{array}{c}\text { Capillary } \\
\text { porosity (\%) }\end{array}$ & $\begin{array}{c}\text { Total porosity } \\
\text { (\%) }\end{array}$ & $\begin{array}{c}\text { Moisture } \\
\text { content (\%) }\end{array}$ & $\begin{array}{c}\text { Soil specific } \\
\text { gravity }\end{array}$ \\
\hline PM-CK & $1.47 \mathrm{Aa}$ & $29.43 \mathrm{Bb}$ & $28.00 \mathrm{Aa}$ & $2.55 \mathrm{Bb}$ & $40.10 \mathrm{Aa}$ & $42.65 \mathrm{Bb}$ & $20.98 \mathrm{Aa}$ & $2.80 \mathrm{Aa}$ \\
\hline PM-1 & $1.25 \mathrm{Bb}$ & $39.97 \mathrm{Aa}$ & $27.15 \mathrm{Aa}$ & $16.40 \mathrm{Aa}$ & $37.50 \mathrm{Ab}$ & $51.20 \mathrm{Aa}$ & $18.59 \mathrm{Ab}$ & $2.54 \mathrm{Ab}$ \\
\hline PM-2 & $1.29 \mathrm{Bb}$ & $43.56 \mathrm{Aa}$ & $30.25 \mathrm{Aa}$ & $16.40 \mathrm{Aa}$ & $37.60 \mathrm{Ab}$ & $54.00 \mathrm{Aa}$ & $20.29 \mathrm{Aa}$ & $2.61 \mathrm{Aab}$ \\
\hline NO. & $\mathrm{pH}$ & Organic matter & Total nitrogen & $\begin{array}{l}\text { Total phosphorus } \\
\qquad \mathrm{g} / \mathrm{kg}\end{array}$ & $\begin{array}{l}\text { Available } \\
\text { nitrogen }\end{array}$ & $\begin{array}{l}\text { Available } \\
\text { phosphorus }\end{array}$ & $\begin{array}{l}\text { Available } \\
\text { potassium }\end{array}$ & Available zinc \\
\hline PM-CK & $7.94 \mathrm{Aa}$ & $18.20 \mathrm{Bb}$ & $1.35 \mathrm{Bb}$ & $0.56 \mathrm{Bb}$ & $100.00 \mathrm{Ac}$ & $19.70 \mathrm{Bb}$ & $165.00 \mathrm{Bc}$ & $0.25 \mathrm{Bb}$ \\
\hline PM-1 & 7.88 Aa & $24.80 \mathrm{Aa}$ & $1.51 \mathrm{Bb}$ & $0.68 \mathrm{Bb}$ & $115.00 \mathrm{Ab}$ & $28.20 \mathrm{Bb}$ & $255.00 \mathrm{Ab}$ & $0.73 \mathrm{Aa}$ \\
\hline PM-2 & $7.72 \mathrm{Ab}$ & 36.37Aa & $2.44 \mathrm{Aa}$ & $1.21 \mathrm{Aa}$ & $134.67 \mathrm{Aa}$ & $74.50 \mathrm{Aa}$ & $447.67 \mathrm{Aa}$ & $1.04 \mathrm{Aa}$ \\
\hline
\end{tabular}

2 Excel and SPSS13.0 were used for statistical analysis. Different capital letters showed significant difference at $\mathrm{P}<0.01$, and different lower-case

3 letters showed significant difference at $\mathrm{P}<0.05$ between different treatments by the LSD method of a one-way ANOVA. $P M-1$ the soil of peach-

4 Morchella intercropping for 1 year; $P M-2$ the soil of peach-Morchella intercropping for 2 years; $P M-C K$ the control group without peach-

5 Morchella intercropping. 
Table 2 (on next page)

Table 2 Soil enzyme activities in peach orchard 
Table 2 Soil enzyme activities in peach orchard

\begin{tabular}{ccccc}
\hline NO. & Catalase $(\mathrm{U} / \mathrm{g})$ & Sucrase $(\mathrm{U} / \mathrm{g})$ & Cellulase $(\mathrm{U} / \mathrm{g})$ & Urease $(\mathrm{U} / \mathrm{g})$ \\
\hline PM-CK & $7.69 \mathrm{Bb}$ & $1.10 \mathrm{Bb}$ & $0.05 \mathrm{Bc}$ & $0.73 \mathrm{Ab}$ \\
PM-1 & $9.25 \mathrm{Aa}$ & $1.20 \mathrm{Bb}$ & $0.09 \mathrm{Ab}$ & $0.82 \mathrm{Aab}$ \\
PM-2 & $9.14 \mathrm{Aa}$ & $2.17 \mathrm{Aa}$ & $0.18 \mathrm{Aa}$ & $0.92 \mathrm{Aa}$ \\
\hline
\end{tabular}

2 


\section{Table 3(on next page)}

Table 3 Economic benefit investigation of peach orchard with peach-Morchella intercropping 
Table 3 Economic benefit investigation of peach orchard with peach-Morchella intercropping

\begin{tabular}{cccccccc}
\hline NO. & $\begin{array}{c}\text { Peach yield } \\
(\mathrm{kg} / \mathrm{mu})\end{array}$ & $\begin{array}{c}\text { Unit price } \\
(\mathrm{yuan} / \mathrm{kg})\end{array}$ & $\begin{array}{c}\text { Fresh Morchella yield } \\
(\mathrm{kg} / \mathrm{mu})\end{array}$ & $\begin{array}{c}\text { Unit price } \\
(\mathrm{yuan} / \mathrm{kg})\end{array}$ & $\begin{array}{c}\text { Fertilizer cost } \\
(\mathrm{yuan} / \mathrm{mu})\end{array}$ & $\begin{array}{c}\text { Other costs } \\
(\mathrm{yuan} / \mathrm{mu})\end{array}$ & $\begin{array}{c}\text { Net income } \\
(\mathrm{yuan} / \mathrm{mu})\end{array}$ \\
\hline PM-CK & 1630 & 7.5 & 0 & 150 & 1150 & 300 & 10775 \\
PM-1 & 1650 & 7.5 & 240 & 150 & 1150 & 9110 & 38115 \\
PM-2 & 1650 & 7.5 & 220 & 150 & 1150 & 7100 & 37125 \\
\hline
\end{tabular}

$2 \mathrm{Mu}$, a unit of area ( $=0.0667$ hectares);Other costs included cost of labor, materials and culture of Morchella, etc. 